\title{
Rule by Law, Government Control and Company Investment Efficiency: Empirical Evidence from China
}

\author{
Ji-fu Cai ${ }^{1}$ \\ ${ }^{1}$ School of Accounting, Jiangxi University of Finance and Economics, China \\ Correspondence: Ji-fu Cai, School of Accounting, Jiangxi University of Finance and Economics, 169 \\ Shuanggang East Street, Nanchang, Jiangxi Province 330013, China. Tel: 86-1-357-696-7011. E-mail: \\ caijifuxdx@126.com
}

Received: July 5, 2012 Accepted: July 23, 2012 Online Published: February 26, 2013

doi:10.5539/jpl.v6n1p85 URL: http://dx.doi.org/10.5539/jpl.v6n1p85

\begin{abstract}
Under the premise of considering the motives and actions of all levels of governments, this paper empirically studies the mechanism and economic consequences of the law and order regulating inefficient investments on a sample of 3201 firm-year observations of listed companies in Shanghai and Shenzhen Stock Exchange in China over the period from 2007 to 2009. Using investment-cash flow sensitivities to proxy for inefficient investment of a company, I provide evidence that the degree of inefficient investments of listed companies controlled by local governments is much higher than that of other companies controlled by central government or non-governments. Furthermore, I find that the level of law and order of a region with high quality can reduce significantly the sensitivity of investment of Chinese listed companies to cash flows, the effect of which is much stronger for listed companies controlled by local governments. According to the conventional interpretations, a lower investment cash flow sensitivity means less investment distortions. However, the improvement of investment efficiency aising from the law and order are not ultimately transferred to the increase in the company's future operating performances, suggesting that the roles of the level of law and order of a region across China playing in controlling company's inefficient investment are limited.
\end{abstract}

Keywords: law and order, government control, inefficient investment, investment-cash flow sensitivity

\section{Introduction}

In a world where there are no tax and transaction costs and information is perfect, Modigliani and Miller (1958) have confirmed that a company's investment decisions are irrelevant to its financing decisions, the market value of a company will be determined only by the future profitability of investment projects and cost of capitals that a company uses, and the company will achieve the maximum market value at the optimal level of investment. However, there are no perfect capital markets in reality. Information asymmetries and transaction costs in the capital markets will give rise to two frictions: adverse selctions and moral hazards. Adverse selection problems in the capital markets will lead to a company to be credit rationed (Stiglitz \& Weiss, 1981). Credit rationing causes the company to bear the additional cost premium for external financing, and makes uncollateralized external financing more costly than internal financing, which results in the company financially constrained and showing obvious preference to internal financing (Myers \& Majluf, 1984), which leads to internal cash flows as an important determinant of investment of a company. When companies with many good investment opportunities are lack of enough internal funds, in view of the higher cost of external financing or capital rationing problem in the capital markets, companies facing financing constraints would be forced to give up some investment projects with positive net present values, which make the companies underinvest. On the other hand, moral hazard problems will aggravate agency conflicts of use of funds between managers and outsider shareholders, which make company's managers overinvest in unprofitable or even lost projects that will reduce shareholders wealth in order to obtain more monetary and non-monetary private benefits related to the large size of the company when managers are not monitored effectively and appropriate incentives are not given (Jensen, 1986). Since external financing will enable managers to face more monitors and constraints arising from the capital markets, managers tend to use internal funds of a company for overinvestment, making investments of a company also significantly positive correlated with internal cash flows. Therefore, in imperfect capital markets, though the true reasons of underinvestment as well as the resulting company's activities are completely different 
from those of overinvestment, both underinvestment and overinvestment will cause the investment expenditures of a company to increase with its internal cash flows, which make investment expenditures of a company very sensitive to its internal cash flows. Thus, according to the fundamentals above, most scholars' studies about the company's inefficient investments are mainly based on investment-cash flow sensitivities as a proxy for inefficient investments of a company and carried on from the perspective of financial constraints and agency conflicts. Fazzari, Hubbard and Petersen (1988), Hoshi, Kashyap and Scharfstein (1991), Oliner and Rude Busch (1992), Gilchrist and Himmelberg (1995) have found that investment-cash flow sensitivities of financially constrainted companies are even higher than those of the non-financially constrainted companies, and regarded the former's more significant investment-cash flow sensitivities as underinvestment evidence caused by financial constraints in the capital markets. Carpenter (1995), Kaplan and Zingales (1997), Cleary (1999), Pawlina and Renneboog (2005) have showed that the company's investment-cash flow sensitivities mainly arises from agency problems of free cash flows, so that the company investment expenditures are an overinvestment activities that managers misuse funds. The research results of Vogt (1994) have showed that there exist obvious under investments for companies with small-scale, high-growth opportunities, low dividend payout ratio, and companies characterized by large-scale, low-growth opportunities, low dividend payout ratio will overinvest.

In China, some scholars have also found that investment expenditures of Chinese listed companies are also sensitive to theirs internal cash flows, which suggests that the investment of listed companies in China is inefficient. However, the theoretical reasons and manifestations of inefficient investments of Chinese listed companies remain controversial among Chinese scholars. Feng Wei (1999), Zheng Jiangzhun, He Xuqiang and Wang Hua(2001), Wei Feng, and Liu Xing (2004) argue that the Chinese companies' investment-cash flow sensitivities is mainly caused by the financial contraints in the capital markets, suggesting that there is underinvestment in company. He Jin'geng, and Ding Jiahua (2001), Zhang Yi, and Li Chen (2005) have found that investment-cash flow sensitivities in Chinese listed companies primarily arise from agency conflict problems, and overinvestments are main manifestations of inefficient investments of a company. LianYujun and Cheng Jian (2007) argue that the reasons why investment expenditures of listed companies in China are very sensitive to internal cash flow are caused by both financial contraints and agency conflict problems. Companies with low financial contraints tend to overinvest, and companies with high financial contraints are prone to underinvest. The research results of Zhang Zhonghua and Wang Zhi (2006) have showed that, according to the different characteristics of enterprises, both overinvestment and underinvestment are sensitive to internal cash flows of a company. Relative to the underinvestment, state-owned controlled companies in China are more likely to engage in overinvestments. On the contrary, inefficient investments of non-state-owned controlled companies include both underinvestment and overinvestment.

Through systematically analyzing the literatures above, I find that, although scholars above have studied enterprise's inefficient investments from many different angles, they mainly confined to the reasons and manifestations of enterprise inefficient investments, and seldom concerned with how to regulate enterprise's inefficient investments. In recent years, a series of studies on law and finance documents have found that the better legal systems in a country protect the investors' rights, (1) the higher the market value of a company is (La Porta et al., 2000; Claessens et al., 2002); (2) the more dispersed the company shareholdings are (La Porta et al., 1999); (3) the smaller the negative effects of information asymmetries on the companies are (Shleifer and Wolfenson, 2002); (4) the more developed formal financial systems of a country are (La Porta et al., 1998); (5) the lower the company's cost of raising funds is (Shleifer and Wolfenson, 2002). Studies above suggest that the improvement of the level of the rule of law in a country to enhance the level of protection for investors' rights will help to alleviate the financial constraints and agency conflict problems a company facing, and thus reduce the degree of investment expenditures of a company deviating from the optimal investment level. While legal systems in China are still backward relative to developed countries on the whole, there are systematic differences in the level of protection for investors across regions in China. Therefore, if the study frameworks for cross country created by La Porta et al (2000) are applied to different regions with the same legal origin in China, I can empirically examine the effects of the level of the rule of law of a region across China on the company's investment efficiency. Related to this issue above, the investment expenditures of a company in a region with high level of rule of law are much more efficient than that in a region with low level of the rule of law in China.

Different from the existing scholars' researches above, this paper, under control of the influences of the motives of all levels of governments in China, mainly studies the relation between the level of the rule of law in a region where Chinese listed companies are registered and investment efficiency of a company. The reasons why I select the rule of law as a main mechanism regulating enterprise inefficient investments are as follows: according to law and finance, the rule of law not only constitutes the most fundamental institution basis supporting economic 
growth of a country, but also is an important institution arrangement creating a limited and effective government (Qian, 2003). At the same time, the rule of law is also an important factor determining the level of a company governance and financial development mode and performance in a country.

The remainder of this paper is organized as follows. Section 2 presents the institutional background and related hypotheses. In section 3, I describe the sample selection, the measurement of variables and methodology. The main results are reported in section 4 . I conclude in the final section.

\section{Theoretical Analysis and Research Hypothesis}

\subsection{Government Control, Levels of Government and Company Investment Efficiency}

Compared with capital markets of developed countries, Chinese capital market is an emerging one with more information asymmetries and higher transaction costs, which cause the investments of listed companies in China more likely to be distorted and inefficient. On the other hand, Chinese capital markets were established during the course of economic transition, whose goal was to solve the fund shortage and the seriously unreasonable capital structures of state-owned enterprises through raising social capital under the premise of not changing the fundamental nature of enterprises which were still owned by the governments. Consequently, in Chinese stock markets, the majority of listed companies come from restructured state-owned enterprises. At the same time, in order to maintain control of state to listed companies, all levels of governments remains the controlling owner of most listed companies. Through restructuring and listing, although governance structures and the regulatory environments state-owned enterprises facing have changed greatly, all levels of governments still have the ability to influence listed companies' activities, such as investments, by means of control rights to listed companies. Therefore, compared with enterprises in developed market economies, the Chinese listed companies' inefficient investments are influenced by imperfect capital markets as well as motives of all levels of governments, which make the nature and degree of inefficient investment among enterprises controlled by different owners significantly distinct. From the perspective of the property rights, though both central government-controlled enterprises and local government-controlled enterprises are all called state-owned enterprises, there are differences in authorities and resources controlled by governments at all levels, which causes different investment modes between central-government-controlled listed companies and local-government-controlled listed companies. Because of generally belonging to monopoly industries concerned with the people's livelihood, the listed companies controlled by central government could engage in investments with a high economic returns by relying on theirs own market monopoly status and policy advantages granted by the central government, and face less financial constraints in support of strong fiscal funds of the central government. On the other hand, since central-government-controlled listed companies are always more severely regulated due to their monopoly power in the markets, and have established relatively sound internal governance structures, which strongly restrict the moral hazard of managers, and may play an important role in alleviating inefficient investments caused by agency problems between outsider shareholders and managers. As a result, generally speaking, the inefficient investments of listed companies controlled by central government are much lower.

On the contrary, the investments of local government-controlled listed companies are more likely to be inefficient and distorted for the reasons below: First, because the authorities of local governments and resources controlled by local governments can not be compared with those of central government, local government-controlled listed companies don't own enough the required funds for investments relative to central government-controlled listed companies. In other words, local government-controlled listed companies are more likely to be financially constrained than central-government-controlled listed companies. Second, owing to administrative decentralization, local governments in China undertake various social responsibilities, such as economic development, employments and the improvements of people's living standard of the jurisdictions, all of which are largely dependent on local economy scale. Therefore, local governments in China have strong inherent incentives to increase jurisdiction's economy scales through substantial investments, all of which are obviously inseparable from the supports of local government-controlled listed companies. As long as local government-controlled listed companies take on the responsibilities for boosting jurisdiction's economic growth, increasing local employments and performing other social functions, and thus become an important platform to achieve the targets of public governance of local governments in China, local governments have strong incentives to implement soft budget constraints for local government-controlled listed companies. In addition, the promotion competition among local government officials and institution designs of performance evaluation of government officials overemphasizing jurisdiction's economic growth further strengthen local protectionism and incentives for local governments to implement soft budget constraints for the local government-controlled listed companies. Therefore, compared with the central government-controlled listed companies, local government-controlled listed companies are less likely to be regulated by jurisdiction's governments. As a result, 
the local government-controlled listed companies are more prone to generate self-interest behaviors, whose managers are less likely to use enterprise funds effectively, and may give rise to higher agency problems. In order to obtain monetary and non-monetary benefits related to large company scale, the managers of the local government-controlled listed companies have more strong incentives to engage in overinvestments, which reduce the company's investment efficiency. Third, though overinvestments of local government-controlled listed companies waste enterprise's scarce resources, overinvestments could expand the local economy scale. and boost local GDP growth, which can not only solve local employments, and maintain jurisdiction's social stability, but also increase local government fiscal revenues and extra-budgetary incomes. Consequently, within certain limits, the local governments will tolerate and acquiesce overinvestment behaviors of local government-controlled listed companies misusing funds. This is one of the reasons which are more likely to cause investment behaviors of local government-controlled listed companies distorted.

Though investments of non-government-controlled listed companies can also promote local economic development, and encourage jurisdiction's employments, and increase local tax, which help achieve local governments social and political goals, the local government officials have also motives to intervene in investment expenditures of non-government-controlled listed companies. However, due to private property rights restrictions and supporting costs of soft budget constraints to enterprises, the effects of local governments on the investment expenditures of non-government-controlled listed companies are usually limited, which make the intervention of local governments in non-government-controlled listed company investment activities much weaker than local government-controlled listed companies (Sappington \& Stiglitz, 1987). In addition, the ideology discriminations in the finance systems and institutional arrangements of the stock markets severing for the state-owned enterprises in China result in that the ability of non-government-controlled listed company to raise external funds is generally weaker than that of the government-controlled listed companies, which make non-government-controlled listed companies face more severely financial constraints. In order to obtain the necessary funds required for investments, non-government-controlled listed companies must pay very high premiums. Therefore, the managers of non-government-controlled listed companies have more strong incentives to use enterprise funds effectively. That is to say, though the investment expenditures of non-government-controlled listed companies may also be distorted and inefficient due to the imperfect capital markets in China, the degree of inefficient investment of non-government-controlled listed companies is significantly less than that of local government-controlled listed companies, and are more likely to arise from underinvestment rather than overinvestment in the form. Based on the systematic analysis above, I could put forward the first hypothesis as follows:

H1: The inefficient investment problems of local government-controlled listed companies are much more serious than that of central government and non-government-controlled listed companies in China, other things being equal.

\subsection{Rule of Law, Government Control and Company Investment Efficiency}

The root reason why financial constraints and agency problems in imperfect capital markets give rise to company investment distorted and inefficient is that there are interest conflicts among shareholders, creditors and company's managements. When the law is imperfect (for lack of effective protection for outsider investors' rights) and there are frictions in the capital markets (information asymmetries and transaction costs), in order to obtain control private benefits, the company managers and controlling shareholders have incentives to expropriate the interests of outsider investors through inefficient investments. To safeguard their own interests against expropriation, the rational response of outsider investors usually reduce or reject the supply of funds when the enterprises demand funds, and claim a higher premium to compensate for expropriated risks, which will inevitably lead to company financing difficult and the shortage of funds, and yield a negative impact on the company's investment activities. Since legal integrity and its enforcement efficiency exogenously determine the level of protection of investors' rights, therefore, that the investors' rights are granted more law protection not only can enhance the wills of outsider investors providing funds to company, and reduce the external financing obstacles of a company, and ease financial constraints faced by enterprises, but also eliminate the expropriation of interests imposed by the insiders on the outsider investors, and mitigate the agency conflicts among shareholders, creditors and the managers. If the effects of the law protection for investors are reflected in the company investment activities, by means of rights granted by the law, outsider investors can impose enough pressure on investment expenditures of a company and deter the managers to overinvest in inefficient projects or industries. Thus, I can reasonable expect that, when the legal systems in a country become more effective, the degree of the distortion of the enterprise investments will reduce.

However, in emerging markets and transitional economies, the enactment and enforcement of the law are 
generally achieved through the political systems, and the contents and enforcement effectiveness of the law may vary depending on the difference in political systems of a country. When the legal departments behave much weaker than the administrative departments in a country, the enforcement effectiveness of the law is often vulnerable to the influence of politicians (Shleifer and Vishny, 1993). Even if the enactments of the law of a country are very perfect, the enforcement of the law can't be independent of the administrative departments because of mixing with political interests (Modigliani and Perotti, 2000). Legislation and law enforcement systems will even expand the space of government officials rent-seeking, and thus bring about negative impact on investor protection (La Porta et al., 1999).

Since the 1978 reform and opening up, though the enactment of law in China has made remarkable progress, and the legal environments across regions as well as the quantity and quality of the legislation in the financial fields have made a significant improvement, as a transitional economy, due to the differences in economic development path across regions, and the effect of unbalanced regional economic development strategy dominated by central government, the level of rule of law across regions in China are in a de facto imbalance. Even if the investors across regions in China enjoy the same national legal systems, the differences in people's law concept, judicial efficiency and enforcement capacity across regions in China make the enforcement effectiveness of the same legal provisions very different, leading to the systematic differences in the level of investor protection across regions in China. In the capital markets, some local governments, in order to defend their own regional interests, may impose much effect on the enforcement process of the laws of investor protection, resulting in that the law enforcement agencies can not perform the rules and reprimand the illegal entities stringently according to the mandatory requirements of the law, and thus show some flexibility and compromise in the course of enforcement of the regulations, which weaken the restriction of laws on the participants in the markets. That is to say, there is "soft constraints" in the process of the law enforcement, such as even smaller probability and weaker intensity of sanctions, the discontinuity of the law enforcement and the misuse of the regulations.

Given that the real rule of law means that the conducts of all people, including government officials, must be regulated and constrained by law, therefore, in a region with good legal environment in China, government officials are more likely to pay attention to their own image and restrict their own conducts, and thus tend to keep an appropriate distance from enterprises and minimize intervention in enterprise activities. At the same time, the decrease in government helps to enterprises and the increase in the strength and possibility of legal punishment will reduce the incentives for managers to expropriate the outsider investors' interests through inefficient investments. Therefore, the improvement the level of rule of law across regions in China not only means the high level of investor protection, but also implies the increase in the enterprise investment efficiency. Since the problems of inefficient investment of local government-controlled listed companies are much more serious relative to other companies, the improvement of rule of law can impose significant effects on the investment efficiency of local government-controlled listed companies. According to the theoretical analysis above, I could put forward the second hypothesis as follows:

$H 2$ : The level of rule of law in a region in China is significantly negative related with the comapny investment distortion, and the relationship between inefficient investment and the level of rule of law is much more pronounced in the local government-controlled listed companies, other things being equal.

\subsection{The Rule of Law, Government Control, Investment Efficiency and Company Future Performance}

Theoretical analysis above has showed that financial constraints or agency conflicts in imperfect capital markets lead to the company investment expenditures deviating from the optimal investment level, and thus giving rise to underinvestment or overinvestment. On the one hand, the underinvestment shows that some projects with net positive present value are not engaged in, on the other hand, the overinvestment indicates that some projects with net negative present value are not abandoned. Given that the market value of a company will usually achieve the maximum at the optimal investment level, when investment expenditures of a company are insufficient or excessive, the future profitability of the company will be adversely affected. If the improvement of the level of rule of law of a region could significantly reduce the inefficient investments of a company, it means that companies underinvesting increase the investment expenditures of projects with net positive present value, and that companies overinvesting cut down the investment expenditures of projects with net negative present value. Therefore, no matter that the form of the inefficient investment is either underinvestment or overinvestment, the improvement of the investment efficiency arising from rule of law will ultimately be reflected in the increase in the future profitability of a company. That is, the future profitability of company in a region with high level of rule of laws should be significantly larger than that of company in a region with low level of the rule of law. Since the improvement of the level of rule of law in a region imposes a strong effect on the inefficient 
investment of local government-controlled listed companies, thus, the role of rule of law playing in enhancing the future profitability of a company is the most obvious in local government-controlled listed companies. Based on the theoretical analysis above, I could put forward the third hypothesis as follows:

H3: The investment future profitability of companies in regions with high level of rule of law will be significantly higher than that of companies in regions with low level of rule of law, and the relationship between the future investment profitability and the level of rule of law is much more pronounced in the local government-controlled listed companies, other things being equal.

\section{Sample Selection and Research Design}

\subsection{Sample Selection and Data Sources}

According to the study purpose of this paper and sample data availability, the initial sample are selected from all non-financial companies listed on Shanghai and Shenzhen Stock Exchange in China during the period from 2007 to 2009. To ensure the validity of the data collected and minimize the effect of other factors on the research results, I exclude from our initial sample those companies whose main operational business has ever experienced substantial change. Also excluded are firms which have extreme outliers and those whose financial information is seriously inadequate or obviously misreported. After screening based on the criteria above, I then obtain a pooled sample with 3201 firm-year observations in total. All data used in this paper, except GDP per capita and the number of lawyers per 100 thousand population across regions in China which are from "China Statistical Yearbook" and "Law Yearbook of China" respectively, are obtained from CSMAR (China Stock Market and Accounting Research) database developed by Shenzhen GTA Information Technology Co., Ltd. of China.

\subsection{Model Specifications and Variable Definitions}

1. In order to test hypothesis 1 and 2 , the following two regression models are used:

$$
\begin{array}{r}
I N V_{i, t}=\beta_{0}+\beta_{1} \text { Growth }_{i, t-1}+\beta_{2} C F_{i, t}+\Sigma I N D+\Sigma Y E A R+\varepsilon_{i, t} \\
I N V_{i, t}=\beta_{0}+\beta_{1} \text { Growth }_{i, t-1}+\beta_{2} C F_{i, t}+\beta_{3} C F_{i t} \times L n L L_{t-1}+\beta_{4} L n G D P_{t-1}+\Sigma I N D+\Sigma Y E A R+\varepsilon_{i, t}
\end{array}
$$

Where: $\mathrm{i}$ and $\mathrm{t}$ are firm and year indicators, respectively; $I N V$ is the firm's capital expenditures in period t, which is measured as cash paid to acquire fixed assets, intangible assets and other long term assets minus net cash received from the sale of fixed assets, intangible assets and other long term assets in period t scaled by beginning of year book value of total assets. Growth is the firm's investment opportunities in period t. In empirical studies, variables commonly used to measure the investment opportunities of a company are Tobin'Q and sale growth respectively. Tobin'Q is calculated as the ratio of the market value of the company to the replacement cost of assets at the start of the fiscal year. The market value of the company is the sum of the market value of the equity, the value of short term debt and the value of long term debt. The replacement cost of assets is the book value of assets. Tobin'Q is an average rather than marginal value (Hayashi, 1982), and its calculation will use stock prices. Due to the inefficiency and functional fixation problems of stock markets in China, employing Tobin'Q to proxy the company's investment opportunities will bring measurement errors. In addition, Alti (2003) has also showed that, since Tobin'Q mainly reflects option value relating to firm long term growth potential but doesn't provide information about investment opportunities in the near-term, Tobin'Q performs as a noisy measure of short-term investment expectations. Thus, to control possible measurement error in Tobin'Q as a proxy for investment opportunities, I use sale growth as a proxy for company investment opportunities to estimate the regression. $C F$ is the firm's internal cash flow and measured as the ratio of net cash flows from operating activities in period $t$ to the beginning of year book value of total assets. Many studies theoretically and empirically have showed that when the company investments are inefficient and distorted, the investment expenditures are very sensitive to internal cash flows. Therefore, if there is an obvious inefficient investment in the listed companies, the regression coefficients on $C F, \beta_{2}$, should be significantly positive. $L n L L$ is the natural logarithm of the number of lawyers per 100 thousand population across provinces in China in period t-1, reflecting the level of rule of law in a region. The interaction term $C F \times L n L L$ in model (2) is used to examine the effect of the level of rule of law across provinces in China on company's investment efficiency. If the coefficient on $C F \times L n L L, \quad \beta_{3}$, is significant and negative, it indicates that, as the level of rule of law of a province improves, the investment distortion of listed companies will reduce, suggesting that the level of rule of law plays an active role in inhibiting the company's inefficient investments. On the contrary, if the coefficient on $C F \times L n L L, \quad \beta_{3}$, is either significantly positive or insignificant, it shows that rule of law has a bad or no effect on the improvement of the company's investment efficiency. LnGDP is the natural logarithm of GDP per capita across regions in China in period $\mathrm{t}-1$, reflecting the level of economic development of a province in China. Finally, I include industry indicators, IND, and year indicators, YEAR, since investment patterns of a company 
may vary across different industries and are affected by fluctuating in macro economic conditions of a province in China. $\varepsilon$ is error term.

2. As for hypothesis 3 , I construct the following regression models to test:

$$
\begin{aligned}
R O I_{i, t+1}= & \alpha_{0}+\alpha_{1} I N V_{i, t}+\alpha_{2} \operatorname{LnLL}_{i-1}+\alpha_{3} I N V_{i, t} \times L n L L_{i-1}+\alpha_{4} \text { Growth }_{i, t}+\alpha_{5} \operatorname{LnTA}_{i, t}+\alpha_{6} \mathrm{~B}_{\mathrm{i}, \mathrm{t}} \\
& +\Sigma I N D+\Sigma Y E A R+\varepsilon_{i, t}
\end{aligned}
$$

In the model (3), ROI is the firm's return on assets in period $t+1$, equal to ratio of the profit before interest and tax in period $t+1$ to the beginning of year book value of total assets, indicating the future profitability of a company. Growth is the company's sales growth in period t, proxying for company investment opportunities. LnTA is the natural logarithm of book value of total assets, used to control the effect of the scale of a company on the future operating performance. $B$ is the ratio of the sum of bank short term loans and long term loans to the book value of the company total assets.

The variable I am interested in is the interaction term between the current investment level in period $t$ and the level of rule of law of a province in period t-1, $I \times L n L L$, which is used to examine the effect of rule of law on the future profitability of investment of a company. A significantly positive coefficient on the interaction term, $I \times \operatorname{LnLL}, \alpha_{3}$, indicates that the improvement of company investment efficiency promoted by the rule of law is ultimately reflected in the future company's profitability. On the contrary, if the coefficient on $I \times L n L L, \alpha_{3}$, is either significantly negative or insignificant, it shows that the rule of law has a bad or no effect on the future company's profitability.

In order to further investigate the effect of government control on company investment efficiency and the role of rule by law playing in improving company investment efficiency, I further classify listed companies into those controlled by central government, local governments or non-government according to the nature of ultimate controller of a company and report regression results for each sub-groups in Table 2, 3 and 4, respectively.

\section{Results}

\subsection{Descriptive statistics}

Table 1 reports descriptive statistics for the main variables used to estimate model (1), (2) and (3). The mean (median) investment expenditure across all firm-years equals to $0.06811(0.04053)$ of prior year's assets, and the standard deviation of company investment expenditure is 0.08766 , indicating that there are large differences in investment expenditures among companies during sample period. The mean (median) company in the sample has a CF of $0.06026(0.05625)$, which is much greater than the median of investment expenditures, showing that, for most of companies, internal cash flow can meet theirs investment expenditure needs. The mean (median) value for the company future one period operational performance is $0.03508(0.04319)$, indicating that companies performed poorly in period $\mathrm{t}+1$ on the whole and some companies have suffered from an even more serious loss (the minimum value of the company future one period operational performance is -0.94853 ).

Table 1. Descriptive Statistics for the main variables

\begin{tabular}{crrrrrr}
\hline Variables & $\mathrm{N}$ & \multicolumn{1}{l}{ Mean } & \multicolumn{1}{l}{ Median } & \multicolumn{1}{l}{ Min } & \multicolumn{1}{l}{ Max } & \multicolumn{1}{l}{ Std } \\
\hline$I N V$ & 3201 & 0.06811 & 0.04053 & -0.26460 & 0.86458 & 0.08766 \\
$C F$ & 3201 & 0.06026 & 0.05625 & -0.46908 & 0.68058 & 0.09048 \\
$R O I{ }_{t+1}$ & 3201 & 0.03508 & 0.04319 & -0.94853 & 0.72898 & 0.09379 \\
$L L$ & 124 & 14.8724 & 9.30 & 1.28 & 62.70 & 14.8351 \\
\hline
\end{tabular}

$I N V$ is the firm's capital expenditures in a given firm-year, which is measured as cash paid to acquire fixed assets, intangible assets and other long term assets minus net cash received from the sale of fixed assets, intangible assets and other long term assets deflated by beginning of year book value of total assets. $C F$ is firm internal cash flow, calculated by net cash flows from operating activities divided by the beginning of year book value of total assets. ROI is return on assets in period $t+1$, equal to ratio of the profit before interest and tax in period $t+1$ to the beginning of year book vale of total assets. $L L$ is the number of lawyers per 100 thousand population across region (province) in China. 


\subsection{Multiple Regression Results}

\subsubsection{Government Control, Levels of Government and Company Investment Efficiency}

Table 2 reports the main empirical results on the model (1). In model (1), the dependent variable is $I N V$. All standard errors are clustered by firms using the Huber-White procedure. In column 2 of Table 2, which reports the regression results of full sample, the coefficient on $C F$ is 0.279 and significantly positive at $1 \%$ level after controlling for effects of the company investment opportunities and industries and years. The estimated coefficient suggests that increasing internal cash flows by one percent on average is associated with an increase in investment of $0.279 \%$. Given that the mean value for $I N V$ in Table 1 is $6.811 \%$, this changes means that the economic significance of the effect is moderate, indicating that company investments are very sensitive to internal cash flows. The results above suggest that investments of listed companies in China are inefficient and distorted.

Table 2. The multiple regression results of the model (1): government control, levels of government and company investment efficiency

\begin{tabular}{|c|c|c|c|c|}
\hline \multirow[t]{2}{*}{ Model } & \multirow{2}{*}{ All sample } & \multicolumn{2}{|c|}{ Government-controlled companies } & \multirow{2}{*}{$\begin{array}{l}\text { Non-government } \\
\text { controlled }\end{array}$} \\
\hline & & Central government & Local government & \\
\hline \multirow[t]{2}{*}{ Intercept } & 0.042 & 0.045 & 0.040 & 0.042 \\
\hline & $22.326 * * *$ & $11.016^{* * *}$ & $14.609 * * *$ & $12.840 * * *$ \\
\hline \multirow[t]{2}{*}{ Growth $_{i, t-1}$} & 0.055 & 0.047 & 0.057 & 0.054 \\
\hline & $10.839 * * *$ & $4.268 * * *$ & $7.697 * * *$ & $6.111 * * *$ \\
\hline \multirow[t]{2}{*}{$C F$} & 0.279 & 0.210 & 0.321 & 0.255 \\
\hline & $17.304 * * *$ & $6.626 * * *$ & $13.550 * * *$ & $8.413 * * *$ \\
\hline Industry & Included & Included & Included & Included \\
\hline year & Included & Included & Included & Included \\
\hline $\operatorname{Adj} R^{2}$ & 0.130 & 0.097 & 0.142 & 0.120 \\
\hline$F-$ Value & $239.509 * * *$ & $33.548 * * *$ & $143.499 * * *$ & $60.759 * * *$ \\
\hline $\mathrm{N}$ & 3201 & 606 & 1718 & 877 \\
\hline
\end{tabular}

T-statistics are presented below the coefficients and are corrected for time-series correlation using Huber-White standard errors clustered by firm; *** indicates two-tailed statistical significance at 1 percent level.

Table 2 column 3, 4 and 5 respectively reports the regression results of sub-groups of central government controlled, local government-controlled and non-government controlled listed companies. It is worth noting that, though the coefficients on $C F$ are all significantly positive at $1 \%$ level in three models, indicating that the investments of central government controlled, local governments controlled and non-government controlled listed companies are all inefficient, there is difference in the extent of inefficient investment. The coefficient on investment-cash flow sensitivity of local government controlled listed companies is 0.321 and much higher than that of central government controlled listed companies and non-government controlled listed companies, which means that the degree of investment distortion of local government controlled listed companies is the most serious in China. Based on the analysis above, I can conclude that the hypothesis 1 is supported empirically. The coefficients on investment opportunities variable Growth are all statistically significant at $1 \%$ level in all regression equations, indicating that companies with high growth opportunities tend to invest more, which suggests that growth opportunities are still an important determinant of investment expenditures for listed companies in China.

This table presents the regression result of equation (1): 


$$
I N V_{i, t}=\beta_{0}+\beta_{1} \text { Growth }_{i, t-1}+\beta_{2} C F_{i, t}+\Sigma I N D+\Sigma Y E A R+\varepsilon_{i, t}
$$

Where INV is the firm's capital expenditures in period t, which is measured as cash paid to acquire fixed assets, intangible assets and other long term assets minus net cash received from the sale of fixed assets, intangible assets and other long term assets in period $t$ deflated by beginning of year book value of total assets. Growth is the firm's investment opportunities. Substituted by sale growth in period t-1. $C F$ is the firm's internal cash flow, calculated by net cash flows from operating activities in period t divided by the beginning of year book value of total assets. IND and Year are respectively industry and year indicators. Model Variables

\subsubsection{Rule of Law, Government Control and Company Investment Efficiency}

Table 3 presents the multiple regression results of model (2), which are used to test the effects of the level of rule of law of a province in China on company's investments. In full sample regression of column 2 of Table 3, the coefficient on interaction term between $I N V$ and $L n L L$ is -0.020 and statistically significant at $1 \%$ level $(\mathrm{t}$-statistic $=-2.766)$, which suggests that investments are significantly less sensitive to internal cash flows for companies in a region with high level of rule of law than for other companies, Indicating that the improvement of the level of the regional rule of law helps reduce the inefficient investments of a company. Since the investors in different regions in China enjoy the same legal systems, the number of lawyers per 100 thousand populations more reflects the differences in the efficiency of law enforcement across provinces. The results also show that improving the efficiency of law enforcement has more practical significance in China. The coefficient on LnGDP is significant and negative at $5 \%$ statistically level, indicating that listed companies in provinces with high level of economic development invest much less, The result above means that speeding up a region's economic development will reduce the investment expenditures of listed companies in the province, which help to inhibit the overinvestments of companies.

Table 3. The multiple regression results of the model (2); rule of law, government control and company investment efficiency

\begin{tabular}{|c|c|c|c|c|}
\hline \multirow{2}{*}{ Model } & \multirow{2}{*}{ All sample } & \multicolumn{2}{|c|}{ Government-controlled companies } & \multirow{2}{*}{$\begin{array}{l}\text { Non-government } \\
\text { controlled }\end{array}$} \\
\hline & & Central government & Local government & \\
\hline \multirow[t]{2}{*}{ Intercept } & 0.103 & 0.085 & 0.169 & -0.024 \\
\hline & $3.916^{* * *}$ & $1.661^{*}$ & $4.447 * * *$ & -0.458 \\
\hline \multirow[t]{2}{*}{$G_{i, t-1}$} & 0.053 & 0.046 & 0.053 & 0.053 \\
\hline & $10.507 * * *$ & $4.230 * * *$ & $7.144 * * *$ & $5.972 * * *$ \\
\hline \multirow[t]{2}{*}{$C F$} & 0.137 & -0.025 & 0.266 & -0.045 \\
\hline & $2.506^{* *}$ & -0.229 & 3.335 & -0.424 \\
\hline \multirow[t]{2}{*}{$C F \times L n L L$} & -0.020 & -0.001 & -0.031 & -0.019 \\
\hline & $-2.766^{* * *}$ & -0.059 & $-2.032 * *$ & $-2.133 * *$ \\
\hline \multirow[t]{2}{*}{$L n G D P$} & -0.006 & -0.004 & -0.013 & 0.007 \\
\hline & $-2.334 * *$ & -0.772 & $-3.399 * * *$ & 1.264 \\
\hline Industry & Included & Included & Included & Included \\
\hline year & Included & Included & Included & Included \\
\hline $\operatorname{Adj}^{2}$ & 0.135 & 0.100 & 0.155 & 0.130 \\
\hline$F-$ Value & $100.818^{* * *}$ & $14.498 * * *$ & $63.780 * * *$ & $27.189 * * *$ \\
\hline $\mathrm{N}$ & 3201 & 606 & 1718 & 877 \\
\hline
\end{tabular}

T-statistics are presented below the coefficients and are corrected for time-series correlation using Huber-White standard errors clustered by firm; $* * *, * *, *$ respectively indicate two-tailed statistical significance at 1,5 , and 10 percent level.

In column 3, 4 and 5 of Table 3, I respectively report regression results of whether the property rights nature of the controlling shareholders of a company affects the role of rule of law playing in improving the investment 
efficiency. Though the coefficient on interaction term $I \times L n L I$ has become insignificantly in the sub-group of central government-controlled listed companies, it is still significant and negative at $5 \%$ level in the sub-groups of local government-controlled listed companies and non-government-controlled listed companies, indicating that the improvement of rule of law can significantly relieve the inefficient investments of local government-controlled listed companies and non-government-controlled listed companies. However, in terms of the effects of rule of law, the coefficient on interaction term $I \times L n L I$ is -0.031 in the sub-group of local government-controlled listed companies, which is much greater than that of non-government-controlled listed companies, suggesting that the role of rule of law playing in improving the investment efficiency is more pronounced for listed companies controlled by local governments. In sum, the empirical evidence above is consistent with Hypothesis 2 that rule of law can significantly improve the company investment efficiency, and the effect is much stronger in local government controlled listed companies. The estimated coefficient on $L n G D P$ is still significantly negative for listed companies controlled by local governments at conventional levels, but it has become insignificant for listed companies controlled by central government or non-governments, suggesting that a regional economic development help to reduce the investment expenditures of local government-controlled listed companies instead of central government-controlled listed companies or non-government-controlled listed companies.

This table presents the regression result of equation (2):

$$
I N V_{i, t}=\beta_{0}+\beta_{1} \text { Growth }_{, t-1}+\beta_{2} C F_{i, t}+\beta_{3} C F_{i^{\prime} t} \times L n L L_{t-1}+\beta_{4} L n G D P_{t-1}+\Sigma I N D+\Sigma Y E A R+\varepsilon_{i, t}
$$

Where $I N V$ is the firm's capital expenditures in period $\mathrm{t}$, which is measured as cash paid to acquire fixed assets, intangible assets and other long term assets minus net cash received from the sale of fixed assets, intangible assets and other long term assets in period $t$ deflated by beginning of year book value of total assets. Growth is the firm's investment opportunities, substituted by sale growth in period t-1. $C F$ is the firm's internal cash flow, calculated by net cash flows from operating activities in period $t$ divided by the beginning of year book value of total assets. $L n L L$ is the natural logarithm of the number of lawyers per 100 thousand population across region (province) in China in period t-1, reflecting the level of rule of law in a region. LnGDP is the natural logarithm of GDP per capita across regions in China in period t-1, reflecting the development level of a region. IND and Year are respectively industry and year indicators.

\subsubsection{Rule of Law, Government Control, Investment Efficiency and Company Future Profitability}

The empirical results of model (3) are reported in Table 4. In column 2 of Table 4, which reports the regression results of full sample, the estimated coefficient on INV is -0.180 and significantly negative at $1 \%$ level, indicating that investment is negatively correlated with company future operational performance, which further confirms that the inefficient investments are mainly caused by overinvestment in China, and thus are more likely to be activities of managers misusing company funds. The coefficient on $L n L L$ is significant and positive at $1 \%$ level, indicating that in provinces where the level of rule of law is high, the company future profitability is much higher than that of companies in provinces with the low level of rule of law, which is consistent with LLSV(2000)'s findings. The interaction term between $I$ and $L n L L$ is -0.003 but insignificantly negative at conventional level, indicating that, although the improvement of rule of law can reduce company's inefficient investments, the increase in investment efficiency is not finally reflected in the company's future profitability, suggesting that the role of rule of law playing in improving the company's investment efficiency is limited. The coefficients on $G$ and LnTA are both significantly positive at $1 \%$ level, indicating that the future profitability of companies with high growth opportunities or large size is much higher than that of other companies. The coefficients on $B$ is significant and negative, suggesting that the future profitability of companies which can borrow more loans from banks is even worse, which implies that the increase in bank loans is not beneficial to the improvement of company's future profitability.

By comparing the regression results across sub-groups of sample in column 3, 4 and 5 of Table 4, I can find that: (1) The coefficient on $I$ is still significantly negative at conventional level for local government-controlled listed companies, however, in the sub-groups of central government-controlled listed companies and non-government-controlled listed companies, it has become statistically insignificant, indicating that the negative correlation between investment and company future operational performance only occurs in local government-controlled listed companies instead of central government-controlled listed companies and non-government-controlled listed companies. (2) The coefficient on $L n L L$ is still significantly positive at conventional level for local government-controlled listed companies, but in the sub-groups of central government-controlled listed companies and non-government-controlled listed companies it has become statistically insignificant, suggesting that the positive effect of rule of law on the company future operational 
performance is much stronger for listed companies controlled by local governments. (3) The coefficients on interaction term $I \times L n L L$ are still insignificant in all sub-groups of the sample, suggesting that, whether listed companies are controlled by central government, local governments or non-governments, the improvement of rule of law has no substantial impact on the increase in the future profitability of listed companies. In other words, there is no substantial difference in the future profitability between listed companies in provinces with high level of rule of law and those in provinces with low level of rule of law. Hypothesis 3 that future profitability will be significantly higher for listed companies in regions with high level of rule of law than for other companies in regions with low level of rule of law, and the relationship between future profitability of a company investment and the level of rule of law is much stronger in listed companies controlled by local governments is not supported. The reason why Hypothesis 3 is not verified may be related with the limited role of rule of law playing in improving the investment efficiency of listed companies. (4) The coefficient on $G$ is the largest in magnitude in sub-group of non-government-controlled listed companies, indicating that the positive effect of growth opportunities on the future profitability is significantly greater for non-government-controlled listed companies than for other listed companies controlled by central government or local governments. On the contrary, the negative effects of bank loans on the future profitability are much greater for government-controlled listed companies than for non-government-controlled listed companies.

Table 4. The multiple regression results of the model (3): rule of law, government control, investment efficiency and company's future performance

\begin{tabular}{|c|c|c|c|c|}
\hline \multirow[t]{2}{*}{ Model } & \multirow{2}{*}{ All sample } & \multicolumn{2}{|c|}{ Government-controlled companies } & \multirow{2}{*}{$\begin{array}{l}\text { Non-government } \\
\text { controlled }\end{array}$} \\
\hline & & Central government & Central government & \\
\hline \multirow[t]{2}{*}{ Intercept } & -0.216 & -0.094 & -0.292 & -0.213 \\
\hline & $-6.794 * * *$ & $-1.880 *$ & $-6.810 * * *$ & $-2.477 * *$ \\
\hline \multirow[t]{2}{*}{$I$} & -0.180 & -0.078 & -0.208 & -0.103 \\
\hline & $-4.481 * * *$ & -0.848 & $-4.637 * * *$ & -1.397 \\
\hline \multirow[t]{2}{*}{$L n L L$} & 0.003 & 0.002 & 0.002 & 0.002 \\
\hline & $4.125^{* * *}$ & 1.460 & $3.097 * * *$ & 1.494 \\
\hline \multirow[t]{2}{*}{$I \times L n L L$} & -0.003 & 0.018 & -0.009 & -0.014 \\
\hline & -0.437 & 1.425 & -1.160 & -0.854 \\
\hline \multirow[t]{2}{*}{$G$} & 0.095 & 0.088 & 0.075 & 0.114 \\
\hline & $18.112^{* * *}$ & $8.120 * * *$ & $11.159 * * *$ & $10.419 * * *$ \\
\hline \multirow[t]{2}{*}{$L n T A$} & 0.011 & 0.005 & 0.016 & 0.010 \\
\hline & $7.043 * * *$ & $2.278^{*}$ & $7.631 * * *$ & $2.433 * *$ \\
\hline \multirow[t]{2}{*}{$B$} & -0.067 & -0.100 & -0.163 & -0.044 \\
\hline & $-13.828 * * *$ & $-5.699 * * *$ & $-14.466^{* * *}$ & $-6.610 * * *$ \\
\hline Industry & Included & Included & Included & Included \\
\hline year & Included & Included & Included & Included \\
\hline $\operatorname{Adj} R^{2}$ & 0.235 & 0.227 & 0.270 & 0.236 \\
\hline$F$-Value & $165.157 * * *$ & $30.629 * * *$ & $106.846^{* * *}$ & $46.188^{* * *}$ \\
\hline $\mathrm{N}$ & 3201 & 606 & 1718 & 877 \\
\hline
\end{tabular}

T-statistics are presented below the coefficients and are corrected for time-series correlation using Huber-White standard errors clustered by firm; $* * *, * *, *$ respectively indicate two-tailed statistical significance at 1,5 , and 10 percent level.

This table presents the regression result of equation (3):

$$
R O I_{i, t+1}=\alpha_{0}+\alpha_{1} I N V_{i, t}+\alpha_{2} L n L L_{t-1}+\alpha_{3} I N V_{i, t} \times L n L L_{t-1}+\alpha_{4} \text { Growth }_{i, t}+\alpha_{5} L n T A_{i, t}+\alpha_{6} \mathrm{~B}_{\mathrm{i}, t}+\Sigma I N D+\Sigma Y E A R+\varepsilon_{i, t}
$$


Where $\mathrm{ROI}$ is return on assets in period $\mathrm{t}+1$, equal to ratio of the profit before interest and tax in period $\mathrm{t}+1$ to the beginning of year book vale of total assets. INV is the firm's capital expenditures in period t, which is measured as cash paid to acquire fixed assets, intangible assets and other long term assets minus net cash received from the sale of fixed assets, intangible assets and other long term assets in period t deflated by beginning of year book value of total assets. $L n L L$ is natural logarithm of the number of lawyers per 100 thousand population across region (province) in China in period t-1, reflecting the level of rule of law in a region. Growth is the firm's investment opportunities. Substituted by sale growth in period t. LnTA is the natural logarithm of book value of total assets, used to control the effect of the scale of company on performance. $B$ is the ratio of the sum of bank short term loans and long term loans to the book vale of the company total assets. $I N D$ and Year are respectively industry and year indicators.

\section{Conclusions}

That private property rights are protected effectively is the premise of investors providing funds to companies, and is also the key to improving the level of corporate governance in a country and preventing the insiders from expropriating the interests of outside investors. In imperfect capital markets, the reasons why financial constraints and agency conflicts give rise to company investments distorted and inefficient are largely related with laws lack of effective protection for investors' rights. Therefore, improving the rule of law in a country so as to raise the legal protection for private property rights will help to reduce financial constraints or agency conflicts faced by the companies, and relieve the negative effect of inefficient investments on the company, and thus improve the future profitability of a company. Based on the theoretical analysis above, this paper, using investment-cash flow sensitivities to proxy for inefficient investment of a company, empirically studies the mechanism and economic consequences of the law and order regulating enterprise inefficient investments on a sample of 3201 firm-year observations of listed companies in Shanghai and Shenzhen Stock Exchange in China over the period from 2007 to 2009. The results show that the degree of investment distortions of local-government-controlled listed companies is much greater than that of central-government-controlled or non-governments-controlled listed companies. The improvement of rule of law can reduce the company inefficient investments, and the relation between rule of law and inefficient investment is even stronger for local government-controlled listed companies. However, the improvement of investment efficiency arising from rule of law is not eventually reflected in increase in the future company profitability, indicating that the roles that rule of law plays in improving the company investment efficiency are limited.

In sum, although the investment distortion of listed companies controlled by non-governments is less than that of listed companies controlled by local government, which investment is not significantly positively associated with future company operational performance indicates that the investments of non-government-controlled listed companies are still an inefficient activity. The results above mean that the inefficient issues of state-owned property rights and the resulting agency conflicts are not bound to be eliminated automatically with the reform of property rights of state-owned enterprises in China. In the context of government interventions and private property rights lack of legal protection, in order to seek effective substitute mechanisms protecting private property rights and avoid potential expropriations imposed by governments, the entrepreneurs of non-government-controlled listed companies have also the inherent demand for overinvesting. Completely contrary to the theoretical expectation that privatization will relieve the agency problems in state-owned controlled companies, under conditions of soft institution constraints, the actual controllers of companies with any type of property rights all have incentives to expropriate the interests of outside investors by means of the their control rights to company. Therefore, in order to solve the inefficient investment problems of Chinese listed companies and radically eliminate the negative effects of inefficient investment on companies as well as investors, in addition to further improving the corporate governance mechanisms and regulating the investment activities of listed companies, I suggest that Chinese government should fundamentally reforms the unreasonable legal systems during economy transition.

\section{Acknowledgments}

Ji-fu Cai acknowledges the financial support of the Youth Project of Social Science Research Foundation of Ministry of Education of China (11JYC630009) and Planning Program for the Humanity Social Science Research of Universities in Jiangxi Province of China (GL1116). All remaining errors and omissions are my own.

\section{References}

Alti, A. (2003). How sensitive is investment to cash flow when financing is frictionless? Journal of Finance, 2, 707-722. http://dx.doi.org/10.1111/1540-6261.00542 
Carpenter, R. (1995). Finance constraints or free cash flow? A new look at the life cycle model of the firm. Empirica, 22, 185-209. http://dx.doi.org/10.1007/BF01384150

Claessens, S., \& Fan, J. (2002). Company governance in asia: a survey. International Review of Finance, 3, 71-103. http://dx.doi.org/10.1111/1468-2443.00034

Cleary, S. (1999). The relationship between firm investment and financial status. Journal of Finance, 54, 673-691. http://dx.doi.org/10.1111/0022-1082.00121

Fazzari, S., Hubbard, R., \& Petersen, B. (1988). Financing constraints and company investment. Brookings Papers on Economic Activity, 19, 141-195. http://dx.doi.org/10.2307/2534426

Gilchrist, S., \& Himmelberg, C. (1995). Evidence for the role of cash flow in investment. Journal of Monetary Economics, 36, 541-572. http://dx.doi.org/10.1016/0304-3932(95)01223-0

Hayashi, F. (1982). Tobin's marginal q and average q: a neoclassical interpretation, Econometrica, 50, 213-224. http://dx.doi.org/10.2307/1912538

Hoshi, T., Kashyap, A., \& Scharfstein, D. (1991). Company structure, liquidity and investment: evidence from Japanese industrial groups. Quarterly Journal of Economics, 20, 33-60. http://dx.doi.org/10.2307/2937905

Jensen, M. C. (1986). Agency costs of free cash flow, company finance and takeovers. American Economic Review, 76, 323-329.

Kaplan, S.,\& Zingales, L. (1997). Do investment-cash flow sensitivities provide useful measures of financing constraints? Quarterly Journal of Economics, 20, 169-215. http://dx.doi.org/10.1162/003355397555163

La Porta, R., Lopez-de-Silanes, F., \& Shleifer, A. (1999). Company ownership around the world. Journal of Finance, 54, 471-517. http://dx.doi.org/10.1111/0022-1082.00115

La Porta, R., Lopez-de-Silanes, F., Shleifer, A., \& Vishny, R. (2000). Investor Protection and Corporate Governance, Journal of Financial Economics, 58, 3-27. http://dx.doi.org/10.1016/S0304-405X(00)00065-9

La Porta, R., Lopez-de-Silanes, F., Shleifer, A., \& Vishny, R., W. (1998). Law and finance. Journal of Political Economy, 106, 1113-1155. http://dx.doi.org/10.1086/250042

Li, Y. X., Du, R., Gao, R., \& Li, N. (2007). Research on the sensitivity between financial constraint and investment expenditure of listed companies in China. Journal of Management Sciences, 1, 82-88.

Lian, Y. J., \& Cheng, J. (2007). Investment-cash flow sensitivity: financial constraints or agency costs? Journal of Finance and Economics, 2, 37-46.

Modigliani, F., \& Miller, M. (1958). The cost of capital, corporation finance and the theory of investment. American Economic Review, 48, 261-297.

Modigliani, F., \& Perotti, E. (2000). Security markets versus bank finance: legal enforcement and investors' protection. International Review of Finance, 2, 81-96. http://dx.doi.org/10.1111/1468-2443.00006

Myers, S., \& Majluf, N. (1984). Company financing and investment decisions when firms have information that investors do not have. Journal of Financial Economics, 13, 187-221. http://dx.doi.org/10.1016/0304-405X(84)90023-0

Oliner, S., \& Rudebusch, D. (1992). Source of the financing hierarchy for business investment. Review of Economics and Stastistics, 74, 643-654. http://dx.doi.org/10.2307/2109378

Pawlina, G., \& Renneboog, L. (2005). Is investment-cash flow sensitivity caused by agency costs or asymmetric information? Evidence from the UK. European Financial Management, 4, 483-513. http://dx.doi.org/10.1111/j.1354-7798.2005.00294.x

Sappington, D. E. M., \& Stiglitz, J. E. (1987). Privatization, information, and incentives. Journal of Policy Analysis and Management, 6, 567-582. http://dx.doi.org/10.2307/3323510

Shleifer, A., \& Vishny, R. (1993). Corruption. Quarterly Journal of Economics, 3, 599-617. http://dx.doi.org/10.2307/2118402

Shleifer, A., \& Wolfenzon, D. (2002). Investor protection and equity markets. Journal of Financial Economics, 66, 3-27. http://dx.doi.org/10.1016/S0304-405X(02)00149-6

Stiglitz, J. E., \& Weiss, A. (1981). Credit rationing in markets with imperfect information. American Economic Review, 71, 393-410.

Vogt, S. (1994). The cash flow/investment relationship: evidence from US manufacturing firms. Financial 
Management, 23, 3-20. http://dx.doi.org/10.2307/3665735

Wei, F., \& Liu, X. (2004). The effect of financing constraints, uncertainty on corporate investment: an empirical analysis of China listed companies. Economic Science, 2, 35-45.

Zhang, Y., \& Li, C. (2005). Ownership, cash flow, and investment. China Economic Quarterly, 4, 229-246.

Zhang, Z. H., \& Wang, Z. (2006). Internal cash flow and listed companies investment in China: a general analysis framework. Modern Economic Science, 6, 58-65.

Zheng, J. H., He, X. Q., \& Wang, H. (2001). Financial constraints in the listed companies investment: explanation from the views of structure of equity. Journal of Finance, 11, 92-99. 